University of Baltimore Law ScholarWorks@University of Baltimore School of Law

Spring 2004

\title{
The Undiscovered Country: Northern Views of the Defeated South and the Political Background of the Fourteenth Amendment
}

Garrett Epps

University of Baltimore School of Law, gepps@ubalt.edu

Follow this and additional works at: http://scholarworks.law.ubalt.edu/all_fac

Part of the Fourteenth Amendment Commons, and the Supreme Court of the United States Commons

\section{Recommended Citation}

The Undiscovered Country: Northern Views of the Defeated South and the Political Background of the Fourteenth Amendment, 13 Temp. Pol. \& Civ. Rts. L. Rev. 411 (2004)

This Article is brought to you for free and open access by the Faculty Scholarship at ScholarWorks@University of Baltimore School of Law. It has been accepted for inclusion in All Faculty Scholarship by an authorized administrator of ScholarWorks@University of Baltimore School of Law. For more information, please contact snolan@ubalt.edu. 


\title{
THE UNDISCOVERED COUNTRY: NORTHERN VIEWS OF THE DEFEATED SOUTH AND THE POLITICAL BACKGROUND OF THE FOURTEENTH AMENDMENT
}

\author{
by GARRETT EPPS*
}

In 1866, Harper's Weekly announced a new series of woodcuts of Southern life with the remark, "[t]o us the late Slave States seem almost like a newlydiscovered country." It is difficult for Americans in the Twenty-First Century, in a culture of cable news coverage and national newspapers, to appreciate just how mysterious the former Confederacy seemed to Northerners in the months after Appomattox. It was not simply that four years of war had made communication between the two halves of the nation difficult--though that was true, and both Northern and Southern society had changed during the searing years of war in ways that people in the other region could hardly imagine. More important was the brute historical fact that there had not been a nation before 1861. The North and South had always been separate societies, socially incompatible, culturally different, and mutually incomprehensible. Now, for the first time, the two halves were to become part of one whole, and Northerners found themselves wondering what their new countrymen were like, and how they planned to behave in the new nation forged by war.

Throughout the second half of 1865 , the states of the old Confederacy were aswarm with Northern visitors with notepads. They included no less a personage than Lieutenant General Ulysses S. Grant, regarded by most Northerners as the greatest man of the age, and Carl Schurz, the legendary German-American leader who had been one of Lincoln's staunchest political allies. ${ }^{2}$ But there were others whose claims to attention arose solely because they were well-known journalists backed by the Northern press. And all had similar questions: How severe was the destruction visited on the former Rebel states? How did Southern people live? What money did they spend, what clothing did they wear, how did they travel, what did they eat? What were their feelings toward the North, and toward the Union

* Professor of Law, University of Oregon. This article is adopted from chapter three of my forthcoming book, Second Founding: How the Framers of the Fourteenth Amendment Transformed American Democracy. I thank the editors of the Temple Political and Civil Rights Law Review for the opportunity to participate in their symposium on the history of the Fourteenth Amendment, and I thank all the other participants in the symposium for their stimulating ideas. I also thank, in particular, my research assistants, Kimberley Shore, Jacqueline Marks, Anne Mortland, and Emmett Soper; my University of Oregon colleagues Rennard Strickland, James O'Fallon, Keith Aoki, and Robert Tsai. The University of Oregon Law School supported my research on this project with a summer research grant from the Luvaas Faculty Fellowship Endowment Fund. My staff assistant, Debby Warren, worked hard on the project as well. Others who read and commented on an earlier draft, or who were otherwise inspirational, include: Jane Harris Aiken, Paul Finkelman, Michael Kent Curtis, Jack P. Maddex, Michael Vorenberg, Paul Haagen, H. Jefferson Powell, Leonard L. Richards, James L. McPherson, Ward McAfee, Michael Holt and David Bradley.

1. Our Artists in the South, HARPER'S WEEKLY, Apr. 28, 1866, at 259.

2. See generally HANS L. TREFOUSSE, CARL SCHURZ: A BlOGRAPHY vii (1982) (noting that Schurz impressed Lincoln in 1860 with his part in the success of the new Republican party by rallying German-Americans to the antislavery cause). 
they had been forced to remain a part of? What were their plans for the four million Southerners of African descent, most of whom had, until the surrender, been held as slaves, persons without rights? And, perhaps most important for the anxious officials in Washington, what were their plans when they regained their place as full citizens of the United States? Would they accept that the war had changed the nation, and the Constitution, forever? Or would they seek to return to the place of mastery they had occupied before Fort Sumter-to become again the haughty Slave Power that anti-slavery Northerners had resented and feared for nearly half a century?

The last question seems strange to us today. The South of late 1865 was a land devastated by war. The North had for decades been richer and more populous than the South. And yet, for half a century before the outbreak of war, many Northerners had hated, resented, and feared the South, and, more than that, had seen the Southern states and their political leaders as the real rulers of the United States. In the $1850 \mathrm{~s}$, anti-slavery politicians had begun to call the South, or at least the small slaveowning elite that ran it, the "Slave Power," a term that came to be as familiar in the years before the war as "intelligence community" or "militaryindustrial complex" is today. For some, the "Slave Power" was a sinister conspiracy that pulled every string and manufactured every seeming coincidence in American life. John Smith Dye, a devoted conspiracy seeker, wrote three books during the 1850s and 60s explaining that the Slave Power had murdered President Zachary Taylor when he proved unresponsive to its wishes, and had poisoned the sugar at a Washington political gathering in 1857, nearly killing President James Buchanan and terrorizing him into slavish obedience to the Slave Power agenda. ${ }^{3}$

But it wasn't just conspiracy theorists who saw the South as the uncrowned monarch of nineteenth century America during the years before Fort Sumter. As historian Leonard Richards notes:

[T] he notion that a slaveholding oligarchy ran the country - and ran it for their own advantage - had wide support in the years before and after the Civil War. It was the basic theme that Abraham Lincoln and his fellow Republicans used in the 1850 s to gain political power. Before that, it was deemed a self-evident truth by scores of prominent northerners. John Quincy Adams, former president of the United States, was a true believer. So were Charles Sumner, senator from Massachusetts; Salmon P. Chase, senator from Ohio; Josiah Quincy, president of Harvard; Horace Greeley, editor of the New York Tribune; and Henry Wilson, future vice president of the United States. Oddly enough, many southerners also regarded the Slave Power thesis as a self-evident truth. Among the more prominent were Alexander Stephens, future vice president of the Confederacy, and the South Carolina Hotspur John

3. Most accounts, then and now, suggest that the barrels of oysters served to the gathered politicos were the real cause of the outbreak of dysentery that affected the President. The probable cause was contamination in the kitchen. For a brief summary of Dye's theories, see LEONARD L. RICHARDS, THE SlaVe POWER: THE FREE NORTH AND SOUTHERN DOMINATION, 1780-1860, at 2 (2000). For an account of Buchanan's illness, see PHILIP SHRIVER KLEIN, PRESIDENT JAMES BuCHANAN: A BIOGRAPHY 268-69 (1962). 


\section{Henry Hammond. ${ }^{4}$}

Elsewhere, I have argued that a thorough understanding of the Slave Power thesis is an important key to understanding the thinking of the anti-slavery politicians who framed the Fourteenth Amendment. ${ }^{5}$ The provisions of the Amendment track quite closely the concerns Northern Republicans had expressed about the Slave Power during the decade before Appomattox-about its political, legal and financial dominance of the Union, and about the undemocratic, internal political system that Southern States maintained, thereby ensuring that free-labor ideas would be forbidden and free-soil politicians excluded from power.

Many more Northerners had fought to end the Slave Power than to end slavery-to put the haughty slavemasters who had ruled the Republic in its first century in their place and reform the political system so that the South could not dominate the federal government and use federal power against the free states. Now, like frightened villagers in a fairy tale, they were asking themselves if the giant could really be dead. Northern journalists, military officers, missionaries and teachers were the eyes and ears of the Northern public as they asked whether the Slave Power had learned its lesson.

Four important American journalists had undertaken tours of the South in the months after the surrender, and all reported to the Northern public that the Slave South, though vanquished, was unbowed, and that its people intended to recreate its prewar system as closely as they could, and then to return to dominate the Union.

The travel book was a stable of nineteenth century publishing-a vicarious chance for readers to journey to distant and exotic lands. And the South was as exotic to Northern readers as Ireland or Bohemia. One of the best sellers of the 1850s had been Our Slave States, a trilogy of travel books by Frederick Law Olmsted, the journalist and landscape architect who is today best remembered as the designer of Central Park. ${ }^{6}$ In 1865, though, he was Associate Editor of a new magazine, The Nation. ${ }^{7}$ Olmsted and the magazine's editor, E.L. Godkin, now commissioned a twenty-seven year-old Harvard graduate named John Richard Dennett to repeat Olmsted's travels and report to the magazine's readers under the weekly heading of "The South as It Is." Dennett was well prepared: he had taken time off from his studies at Harvard to work for a year in the Sea Islands of South Carolina, where Union troops in 1861 had seized plantations belonging to Southerner owners who had fled.9 The soldiers had begun the famous "Port Royal Experiment," in which the black slaves-who would not be legally freed for more

4. RICHARDS, supra note 3, at 1-2.

5. See Garrett Epps, The Antebellum Political Background of the Fourteenth Amendment, 67 LAW \& CONTEMP. PROBS. (forthcoming 2004).

6. See Arthur M. Schlesinger Jr., Editor's Introduction to FREDERICK LAW OLMSTED, THE CotTon KINGDOM: A SELECTION ix-lvi (Arthur M. Schlesinger Jr. ed., 1996) (1972) (recounting Olmsted's career and details of publication of original trilogy).

7. See JOHn RICHARd DENNETT, THE SOUTH AS IT Is, 1865-1866, at vi (Henry M. Christman ed., Louisiana State Univ. Press 1965) (1866) (noting that Frederick Law Olmsted was a major sponsor of The Nation as well as the architect and writer for the magazine).

8. Id. at vii-viii.

9. Id. at vii. 
than a year-were put to work under free-labor conditions and paid wages. ${ }^{10}$

Horace Greeley, the premier anti-slavery newspaperman of the North, commissioned another journalist, Whitelaw Reid, to travel south at about the same time. Dennett had to jostle over Southern railroads; Reid traveled in style down the coast in a military packet carrying Salmon P. Chase, Chief Justice of the Supreme Court, a veteran anti-slavery politician, former Secretary of the Treasury, and perennial presidential hopeful (he had actively schemed to displace Lincoln on the ticket in 1864).." Sidney Andrews reported on his own Southern travels for The Chicago Tribune (a Republican newspaper that jousted with Greeley's New York Tribune for the title of leading anti-slavery paper) and the even more deeply antislavery Boston Daily Advertiser. ${ }^{12}$ Andrews was a hardscrabble Midwestern journalist who had moved to Washington during the war and worked as a Senate attendant, filing savvy political reports as "Dixon," the name he used on his Southern travels as well. ${ }^{13}$ Most prominent of the literary travelers was John Townsend Trowbridge, at thirty-eight already a well-known anti-slavery novelist and poet. Trowbridge had briefly served as editor of The Washington Sentinel, which was owned by Ben Perley Poore, the doyen of Washington correspondents. When the Fugitive Slave Law of 1850 passed the Senate, Trowbridge had let fly with such a vicious editorial campaign against it that he had almost bankrupted the Sentinel. Poore had to return from his sabbatical, and Trowbridge had returned to Boston. The subscription publisher L. Stebbins now sent him south to prepare a travel volume for the spring list of $1866 . .^{14}$

Taken together with Carl Schurz's report, the dispatches filed by these reporters tell us a good deal about life in the South during 1865 and early 1866the period in which the Thirty-Ninth Congress was reshaping the Constitution. Each writer had his own special concerns-Andrews was fascinated by the proceedings of the Southern conventions called by the newly appointed military governors; Dennett gave a picture more closely focused on day-to-day life; Reid chronicled many gatherings of prominent Southerners, who turned out to greet the Chief Justice, as well as many scenes between this most prominent of political abolitionists and the former slaves he had worked to free; and Trowbridge was more concerned with the picturesque than the others, and gave haunting glimpses of the desolate battlefields where the armies had fought just months before.

But inevitably their accounts tell us as much, if not more, about what Northerners were thinking-and fearing-about their traditional foes. None of the correspondents provides an especially rich picture of life among the freed slaves. Like most Northerners of the time, they found black Americans exotic, and their patronizing attitudes seem to distort much of their reporting. But their real

10. James M. MCPherson, THE Struggle for Equality: Abolitionists and the Negro in THE CIVIL WAR AND RECONSTRUCTION 158-60 (Princeton Univ. Press 2d ed. 1995) (1964).

11. WHITELAW REID, AFTER THE WAR: A SOUTHERN TOUR 10 (C. Vann Woodward ed., 1866).

12. Sidney ANDREWS, THE SOUTH Since THE WAR i (William Loren Katz ed., Arno Press 1969) (1866).

13. Id. at ii.

14. John T. Trowbridge, The Desolate South: 1865-1866, at iv (Gordon Carroll ed., Duell, Sloan \& Pearce 1956) (1866). 
curiosity was about white Southerners, about the haughty planters, politicians and merchants who had made up the Slave Power. And even though each man brought different experiences to bear on what he saw, and traveled different itineraries across the defeated South, their observations were remarkably consistent. They reported that the South, though defeated in battle, did not realize how much the war had changed America.

On one level, Southerners owned their defeat. Andrews reported that one octogenarian delegate had told the South Carolina convention, "If the youngest of you lives to my age even, you will not see another musket shouldered in the South against the Union."15 Everywhere they traveled, the reporters met former Confederate officials and soldiers who freely confessed their defeat and their weariness of war. ${ }^{16}$

But there were other fields of battle-politics, Congress, and the Constitution-and in those struggles the South expected nothing less than victory. Throughout the history of the Republic, Southerners had dominated the White House, the Supreme Court, and Capitol Hill. With the end of the fighting, Southerners saw no reason why they should not simply resume their traditional leading role. Slavery, as such, was abolished now. White Southerners admitted that-and thought that they were being liberal in doing so. But in all other respects, Southerners expected to be allowed to run their own states behind the shelter of "state sovereignty" - and to receive a bonus of federal political power for the oppressive and undemocratic features of their local institutions.

The spirit of confidence was more striking because it came from a region so thoroughly devastated by war. Southern society had collapsed economically, Reid explained:

Everything has been mended, and generally in the rudest style. Windowglass has given way to thin boards .... Furniture is marred and broken, and none has been replaced for four years. Dishes are cemented in various styles and half the pitchers have tin handles. A complete set of crockery is never seen .... A set of forks with whole tines is a curiosity . .. . [H]ats, bonnets, and ladies' and children's shoes, are nearly all homemade. Hair-brushes and tooth-brushes have all worn out; combs are broken, and are not yet replaced; pins, needles, thread, and a thousand such articles, which seem indispensable to housekeeping, are very scarce. Even in weaving on the looms, com-cobs have been substituted for spindles. Few have pocket-knives. In fact, everything that has heretofore been an article of sale at the South is wanting now. At the tables of those who were once esteemed luxurious providers, you will find neither tea, coffee, sugar, nor spices of any kind. Even candles, in some cases, have been replaced by a cup of grease, in which a piece of cloth is plunged for a wick. ${ }^{17}$

Northerners had not esteemed Southern cuisine even in flush times; now that

15. ANDREWS, supra note 12 , at 95 .

16. Id. at 95 .

17. REID, supra note 11 , at 224. 
most meals consisted of pork, lard and commeal, the region's diet seemed positively subhuman. By the time he reached Corinth, Mississippi, though, Trowbridge's culinary standards had sunk, so that he reported with satisfaction a particularly sumptuous repast of "fried pork, fricasseed gray squirrel (cold), boiled 'back of hog' (warmed up), a pitcher of milk, cold biscuit, cold corn bread, and 'sweet bread' (a name given to a plain sort of cake)."18

But most desperate of all was the Southern need of money-any form of itthat could be spent for things they could not sew or shoot themselves. Confederate notes were valueless. In their place were only scant reserves of silver and gold. Most citizens had lent their hard money to the Confederate government in exchange for now-worthless paper. Now they were confronted with something Southerners had never seen before, because they had been unknown when the Union split asunder in 1861: national money, issued and backed by the Federal Treasury. Dennett found farmers and merchants in North Carolina who had never seen the new notes, which were ubiquitous throughout the North. ${ }^{19}$ Those who would accept them insisted on a steep discount from prices set in silver or gold. From bitter experience with the Confederate government, most Southerners assumed the notes would be repudiated by the Union. "Won't be worth a copper in two years," one merchant assured the reporter. ${ }^{20}$

Yet amid the poverty and destruction, there were signs of immediate growth. In the spring of 1865, Reid found Mobile "a city of ruins."21 Returning six months later, he rubbed his eyes in amazement at the sight of frantic rebuilding, as former Rebel soldiers thronged the bars to do business with Northern speculators. ${ }^{22}$ Atlanta, burned by Sherman, presented an even more electric prospect when Andrews got there-" narrow and irregular and numerous streets are alive from morning till night with drays and carts and hand-barrows and wagons ... with a never-ending throng of pushing and crowding and scrambling and eager and excited and enterprising men, all bent on building and trading and swift fortunemaking." 23

But what Southern phoenix would rise from the ashes? Would it be a new democratic region of free labor and free speech, or the old South reborn, with its imperious planters, scheming politicians, docile voters and cowed blacks, slaves once again in all but name? To the visitors in 1865 , the portents were ominous. The Republicans, victors in 1860 as in 1865 , had always assumed that an end to slavery would raise to power a new class of anti-slavery Southerners, committed to the same values as their counterparts in the North. But this had been a miscalculation. "The theory of reorganization, which prevailed during the war, based itself upon the belief in the existence of a Union party at the South," Reid wrote. ${ }^{24}$ After his travels, he concluded, "[t]here was no such party." 25 There were,

\footnotetext{
18. TROWBRIDGE, supra note 14 , at 166 .

19. DENNETT, supra note 7 , at 147.

20. Id. at 232 .

21. Id at 402 .

22. Id. at 402-03.

23. ANDREWS, supra note 12 , at 340 .

24. REID, supra note 11 , at 404.
} 
to be sure, "Unionists" everywhere abroad in Dixie in 1865-but even for those who had adopted scalawag garb only after Appomattox, "Unionism" was insubstantial stuff, made up mostly of antagonism toward the planter class and liberally mixed with hatred and contempt of the freed slaves. "These men loved not the Union more," Reid reported, "but Jeff. Davis less." ${ }^{\text {"26 }}$ Andrews reported from North Carolina that '[m]uch of the 'Unionism' of the State is mere personal bitterness toward Jeff Davis, or Governor [Zebulon] Vance, or some less noted secession leader." 27 Such Unionism, he concluded, was "a cheat, a will-o'-thewisp, and any man who trusts it will meet with overthrow." 28 Most of these "Unionists" were so-called because they had opposed secession in 1861; but most of them had then "followed the state," assuming public office or military rank under the Confederacy. Southern whites who had refused to support the Confederacy had lived through four bitter years of isolation; and even in the wake of occupation, their lives were at best tenuous, and they reported constant danger from unrepentant Rebels.

Yet, curiously, on most of the issues that concerned the Northern public in 1865 , the "Unionists" and the old Rebels were pretty much in agreement. Most importantly, most white political figures in the South agreed that, having lost the war, the Southern States were entitled by right to immediate re-entry into the Union, with little or no change in their constitutions or societies. The Constitution, as they had known it, guaranteed the sovereignty of every state, and made it in all but a few spheres superior to the federal government. The battles of the past four years had changed the military facts, Southern whites argued; they had not changed the Constitution or the power of the individual state. Visiting the Georgia state convention, Andrews reported, "[t]he State rights heresy was as dominant in this Convention, almost, as in [the secession convention] of 1861." ${ }^{29}$ Among the educated classes, there was "[n]ot merely a broad assertion of the rights of the States, but an open enunciation of the supremacy of the State over the general government ...."."30

Most Southerners were willing to admit that slavery was abolished, though they were often careful to add words like "by the military power of the United States" to indicate some question about the issue. The Thirteenth Amendment (which most Americans in 1865 called simply "the Amendment," because it was the only one adopted in their lifetimes) was not yet ratified, and many Southern whites told Carl Schurz that they would be willing to "accept" it—as long as it was rewritten to omit the section granting Congress the power to enforce its provisions, which they saw as compromising their state's prerogatives.

Those prerogatives were absolute, they said, and Congress could do nothing to abridge them. Southerners intended to have their representatives in Congress right away, without any further "reconstruction." When Southern members reached

\footnotetext{
25. Id.

26. $I d$.

27. ANDREWS, supra note 12 , at 184-85.

28. Id. at 391 .

29. Id. at 283 .

30. Id. at 333 .
} 
Congress, one Georgian told Sidney Andrews, "We're not going there to ask favors, by G-D, but to demand our rights!" 31 Another was more pacific, but no less firm, in his words to Whitelaw Reid:

We tried to leave the Union. You have defeated us in our effort. What can there be, then, for us to do but to return our Senators and Representatives to the Congress from which we tried to withdraw forever? We acknowledge the defeat, and are ready to send back our Congressmen. That is what you have been fighting for; what more can the General Government have to do with the matter? ${ }^{32}$

As for civil liberties, the privilege of voting, and the rights of the freed slaves, Southerners of all stripes agreed-these were internal matters, given over entirely to state government, about which a meddling Congress could have nothing whatsoever to say. ${ }^{33}$

As far as many white Southerners were concerned, it was not just a matter of resuming their representation in Congress. The South, with its political unity and its lucrative cotton crop, had always dominated American politics, and expected to do so again. "We'll unite with the opposition up North, and between us we'll make a majority," one former federal officeholder told Whitelaw Reid. "Then we'll show you who's going to govern this country." 34

In fact, as far as many Southerners were concerned, the process of restoring regional rule had already begun. Andrew Johnson was a Southerner, and in the months since Appomattox he had abandoned the angry rhetoric about treason and set to work restoring the South to eminence. White Southerners hailed his efforts and expressed hearty support for him. In Georgia, politically savvy Southern men explained to Andrews that Johnson clearly had chosen the South as his base for a presidential run in 1868, and that "the South and the Democratic party could elect him then." ${ }^{35}$ Another Georgian explained that "[w]e must strike hands with the Democratic party of the North, and manage them as we always have ... . [T] hey were ready enough to give us control if we gave them the offices; and I reckon they've not changed very much yet." 36 Wade Hampton, a former secessionist firebrand and Confederate general, told the people of South Carolina that "it is our duty to support the President of the United States so long as he manifests a disposition to restore all our rights as a sovereign State." ${ }^{37}$

Whitelaw Reid found that politically involved Mississippians expected Johnson to sweep away Republican opposition in Congress, by fair means or foul. "There's no use in you Yankees talking," one said. ${ }^{38}$ "Johnson can force through

31. Id. at 320.

32. REID, supra note 11 , at 264.

33. Id. at 404.

34. Id.

35. ANDREWS, supra note 12 , at 233.

36. Id. at 355 .

37. Id. at 391.

38. REID, supra note 11, at 393. 
Congress anything he wants." 39 Others suggested that Republican opposition might anger the President and lead him to a coup d'etat. "Hasn't he the army?" one group asked archly, while another was less subtle.40 "Johnson isn't going to put up with your radicals any longer. He is going to prorogue Congress at once, to get rid of its meddlesome interference with his policy!"41

Dennett found much the same spirit in Vicksburg. "Johnson's doing very well now. He don't believe much in the niggers, neither, and when we're admitted into congress we're all right. The men that tyrannize over us now won't be in a majority then," one Southern pundit explained. ${ }^{42}$ "All the men, North and South, that are conservatives, must unite together. There are some men at the North that behaved very well all through the war, and we must unite with them." ${ }^{\prime 43}$

Once they returned to authority, Southemers said, they would make a few changes in the postwar economic setup. To begin with, there was the issue of back taxes. Early in the war, Congress had approved a $\$ 20$ million "direct tax" on the states. $^{44}$ In the years before the income tax, peacetime federal revenue came almost exclusively from duties on imported goods. But when an emergency arose, the Union could simply demand cash from the states, assessed per capita on a basis of population. So the South's share of the 1861 levy was nearly $\$ 10$ million-plus interest, of course. ${ }^{45}$ Southerners didn't think that was fair. And beyond that, there was the issue of the national debt. Ever since the rise of Andrew Jackson in 1828, low debt had been a watchword in American politics. But when Lincoln in 1861 found himself with an empty treasury and half the Union in revolt, he and Treasury Secretary Chase had persuaded Congress to throw caution to the wind. By 1865 , the national debt totaled $\$ 2.6$ billion-nearly thirty times what it had been in 1861 - and required regular interest payments of $\$ 137$ million a year. Federal taxation to pay off the Union debt was, Schurz reported with some restraint, "very unpopular in the South." One South Carolinian told Sidney Andrews that "the President would not require the south to pay any part of the national debt. 'What, ruin us, and then make us help pay the cost of our own whipping? I reckon not!"'46 Indeed, the only question to many Southerners was whether the South should be exempted-or the entire national debt should simply be repudiated, like the Confederate debt after Appomattox. A tavern keeper in Southside, Virginia

39. Id.

40. Id. at 318-19.

41. Id. at 567.

42. DENNETT, supra note 7, at 351.

43. Id.

44. Phillip Shaw Paludan, A People's Contest: The Union and Civil War, 1861-1865, at 117 (Theodore A. Wilson ed., Univ. Press of Kansas 2d ed. 1996) (1988).

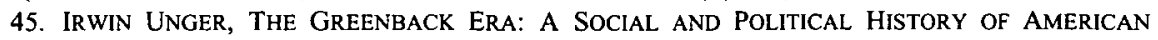
FINANCE, 1869-1879, at 16 (1964).

All told, the Lincoln government spent well over $\$ 3$ billion for all purposes during the four years of conflict. Less than a fifth of this was paid for by taxes, leaving the federal debt at over $\$ 2.8$ billion at its highest point in August 1865, when it equaled about one-half the annual gross national product. This was by far the largest debt the nation had ever experienced, and the interest on it alone far exceeded the total federal debt before 1861 .

Id.

46. ANDREWS, supra note 12 , at 219. 
assured John Dennett that the Union bonds "were going to be repudiated in less than twelve months." ${ }^{47}$ In Georgia, a state convention delegate pointed out to Whitelaw Reid that it wasn't fair for Union bonds to be paid off while Confederate securities were worthless. ${ }^{48}$ "If that Confederate debt isn't honestly due no debt in the world ever was," he said. 49 "If we've got to repudiate that, we may as well help the Democrats repudiate the debt on the other side too. What's fair for one is fair for the other." 50

And the whole issue of Southern debts incurred to pay for the war would get another look once the South was back. The Northern travelers found few Southerners who were willing to argue for repayment of the $\$ 700$ million debt run up by the Confederate States of America (CSA). The CSA had ceased to exist-its president, Jefferson Davis, was imprisoned in Fortress Monroe south of Richmond - and most Southerners had never felt much allegiance to the Richmond government. Most of the debt was owed to foreign investors, but the Confederate state governments also owed about $\$ 54$ million. Much of that money had been borrowed from well-to-do whites in each state, and many of the leaders of the new state governments thought they ought to pay that money. True, it had been borrowed to fund a war against the Union, but few whites in the South thought the attempt at secession had been wrong or illegal, and the fact that the Union Army had defeated Lee's troops didn't change that. Andrew Johnson had suggested to the new governments that they repudiate that debt, and had found them remarkably reluctant to do so. Sidney Andrews found overwhelming majorities of the conventions in both South Carolina and Georgia in favor of requiring repayment of the state debts. ${ }^{51}$ When it became clear that even this president would not accept them back into the Union without repudiation, the conventions rather reluctantly assented-for the moment. One Georgia delegate pointed out that the issue could always be revisited: "Let us repudiate only under the lash and the application of military power, and then, as soon as we are in independent sovereignty, restored to our equal rights and privileges in the Union, let us immediately call another Convention and resume the debt." 52

Beyond the state debt, though, Southerners had another financial issue they expected the federal government to deal with. Lincoln's Emancipation Proclamation had freed the slaves. Now the South was ready to present its bill for this confiscation of valuable property. "There are abundant indications in newspaper articles, public speeches, and electioneering documents of candidates, which render it eminently probable that on the claim of compensation for their emancipated slaves the Southern States, as soon as readmitted to representation in Congress, will be almost a unit," Schurz told Johnson. ${ }^{53}$ "I 'low the gov'ment won't take away all our niggers for nothin'," one North Carolinian explained to

47. DENNETT, supra note 7, at 91 .

48. REID, supra note 11 , at 357.

49. Id.

50. Id.

51. ANDREWS, supra note 12 , at 260-61.

52. REID, supra note 11 , at 358 .

53. ANDREWS, supra note 12, at 218. 
Andrews, ${ }^{54}$ "[t]he Cons'tution makes niggers prop'ty, and gov'ment is bound to pay for them." $" 55$

Southerners were quite confident that their Congressional votes, coupled with those of Northern Democrats, would get them a good deal economically. Domestically, too, the restored union these Southern political thinkers envisioned would be much like the antebellum republic-complete with Southern control over words written and spoken in the South, the pervasive prewar censorship that historian Clement Eaton called "the intellectual blockade." 56 The almost complete lack of free speech and debate in the old South had been one of the main criticisms offered by anti-slavery orators during the 1850 s. As Reid noted, "[p]ersons writing from here in the spring of 1861 , said there was no feature of the feeling among the leaders more marked than their scarcely disguised hostility to the freedom of the press." $57 \mathrm{He}$ found that feeling still general: "The newspapers found it difficult to realize that free speech and free press were at last established. The Montgomery Mail thought these correspondents from the North ought to be kept in their own section-they did nothing but misrepresent and slander." ${ }^{18}$ Schurz in his report reminded Johnson that:

One of the greatest drawbacks under which the southern people are laboring is, that for fifty years they have been in no sympathetic communion with the progressive ideas of the times. While professing to be in favor of free trade, they adopted and forced a system of prohibition, as far as those ideas were concerned, which was in conflict with their cherished institution of slavery; and, as almost all the progressive ideas of our days were in conflict with slavery, the prohibition was sweeping .... This spirit, which for so long a time has kept the southern people back while the world besides was moving, is even at this moment still standing as a serious obstacle in the way of progress. ${ }^{59}$

This system of thought control seemed to mock the Constitution's promise that every state would be required to maintain a "republican form of government." 60 Southern postmasters had barred Northern publications from the mail, and informal violence by individuals and secret "vigilance committees" had driven dissenting whites into silence or exile. Now those committees were reappearing. One Alabama Unionist showed Whitelaw Reid a note he had received:

Sir: We, the undersigned citizens of Mobile, Ala., give you one week from date to leave the place, and if found within the limits of the city or State after the time specified as above, you and your traitorous offspring

56. Clemont Eaton, Freedom of Thought StRuggle in the Old SOUth 331 (1940).

57. REID, supra note 11, at 375.

58. Id.

59. Carl Schurz, Report on the Condition of the SOUTH 40-41 (William Loren Katz ed., Arno Press 1940) (1865).

60. U.S. CONST. art. IV, $\S 4$. 
will be wiped into eternity as sure as there is a God above you.

By order of

Special CommitTeE. ${ }^{61}$

In New Orleans, Reid was told of a secret society that had made plans to drive all "Yankees" out of the city as soon as federal troops withdrew. And a planter in a rural Louisiana parish was subjected to another secret missive for the crime of leasing land to black farmers: "we have decided to burn more than your gin-house, and will kill you if you don't break up your infamous nigger camps."62 Dennett warned his readers that any Northerner emigrating South "would be compelled to restrict his accustomed freedom of speech and action and defer to the social and political theories and opinions of his neighbors." 63 Sidney Andrews found that out personally, when rumors spread around Albany, Georgia, that this Yankee visitor had taken the side of a black man in a fistfight with a white. Andrews was tracked by a lynch mob, and had to be spirited out of town. ${ }^{64}$

Having been united so long on slavery, white Southerners were now, the correspondents reported, united in their fear and hatred of the freed slaves. It was, Sidney Andrews found, almost all they talked about: "Everybody talks about the negro, at all hours of the day, and under all circumstances .... Let conversation begin where it will, it ends with Sambo."65 Southerners "accepted" that Lincoln had freed the slaves - at least for the time being - but mere legal freedom did not make them citizens, it made them "free blacks," a tightly restricted legal status that had existed before the Civil War. With Emancipation, one Union officer told Schurz, the whites had concluded that "the blacks at large belong to the whites at large."'66 Andrews noted that even if Southern whites overtly "accepted" emancipation, almost none of them accepted that blacks were human beings, much less fellow citizens. "The negro is an animal whose character the North seems utterly unable to comprehend," " one South Carolina convention delegate told him. ${ }^{67}$ That, he concluded, was the voice of Southern opinion: "the negro is an animal; a higher sort of animal, to be sure, than the dog or the horse, but, after all, an animal."68

What that meant, to many Southerners, was that a legal system would have to be devised quickly to keep the "freed" slaves in their proper place - preferably on the plantations, laboring for their old masters. These "black codes," which were passed by many restored Southern legislatures in the fall of 1865 , in essence made black Southerners wards of the state, granting officials authority to bind them out under contract to planters in need of hands. Blacks found wandering abroad without regular employment for a white master were subject to whipping, followed

61. DENNETT, supra note 7 , at 300 .

62. Id. at 344 .

63. Id. at 273.

64. ANDREWS, supra note 12, at 294-300.

65. Id. at 22 .

66. SCHURZ, supra note 59 , at 32 .

67. ANDREWS, supra note 12 , at 87 .

68. Id. 
by imprisonment. These "convicts" were then to be used for forced labor on public works, or leased to masters who would obtain their labor in exchange for paying off their fines. Black families were to be broken up again, as in slavery times, as well-a number of the "black codes" empowered local judges to seize the children of black parents and "apprentice" them to white masters. Preference, in some of the codes, was to go to the children's former owners. ${ }^{69}$

Such harsh measures-slavery in all but name-shocked Northern readers. In late 1865, shortly before Congress assembled, Horace Greeley's New York Tribune ran a report on South Carolina's new "black codes" under the provocative headline, "SOUTH CAROLINA RE-ESTABLISHING SLAVERY." Bo But to many of the Southerners reporters talked to, the "black codes" were just a way station toward re-establishment of the old "peculiar institution" in all its glory. One man in Lynchburg told Dennett that the blacks "seem to think they be" free-but that "we can tell better when the next Congress meets and after the Supreme Court has decided."71 The reliance on the Supreme Court to give back their slaves was not as quixotic as it seemed-the Court had held in Dred Scott that black Americans were not and never could be citizens of the United States, no matter what Congress decided. ${ }^{72}$ Southerners had dominated the Court before the war, and the vast majority of Justices had been slaveowners and pro-slavery men. Southerners often spoke of Emancipation as a military measure. The Constitution had not yet been amended to bar slavery, and so the hope that they could win back in Congress or in court what they had lost in war was not completely absurd.

Nevertheless, most educated Southerners understood that they were unlikely to get back the old system of individual chattel slavery. They were prepared, however, with a new system, which would use racially discriminatory statutes, debt peonage and the criminal courts to make blacks slaves of society in general. Schurz reported to Johnson that he had found throughout the old Confederacy "a desire to preserve slavery in its original form as much and as long as possible ... or to introduce into the new system that element of physical compulsion which would make the negro work." 73 This "new system," he wrote, would not be "slavery in its old form," but instead a system "intermediate between slavery as it formerly existed in the South, and free labor as it exists in the North, but more nearly related to the former than the latter."${ }^{.74}$

Many of the South's best brains were at work on how the new system could be smoothly installed. Andrews reprinted a speech by one Confederate veteran in Georgia, which explained that the new constitutional amendment allowed involuntary servitude as "punishment for crime."

69. See generally THEOdORE BRANTER WILSON, THE BLACK CODES OF THE SOUTH (1965) (describing "black codes" and their relationship to the antebellum status of "free blacks").

70. South Carolina Re-Establishing Slavery, N.Y. DAILY TRIBUNE, Nov. 14, 1865, at 4.

71. DENNETT, supra note 7, at 90.

72. Dred Scott v. Sandford, 60 U.S. 393, 405-06 (1856).

73. SCHURZ, supra note 59, at 17.

74. See id. at 19 ("[M] any attempts were made to introduce into that new system the element of physical compulsion ... by simply adhering, as to the treatment of laborers, as much as possible to the traditions of the old system.").

75. ANDREWS, supra note 12, at 324. 
law that would "enable the judicial authorities ... to sell into bondage again those negroes who should be found guilty of certain crimes." Another Georgian veteran cheerfully told Andrews of "private talk" of making "the penal code take [the negro] back into the condition of slavery. It'll be called 'involuntary servitude for the punishment of crime,' but it won't differ much from slavery."'77 In Selma, Alabama, Trowbridge found, city authorities were already putting such a system in place. He saw a chain gang of black men working on the streets; they had been convicted of " "using abusive language towards a white man," or of selling produce at the public market before the opening bell. ${ }^{78}$ "'That's the beauty of freedom!" onlookers told him as they pointed to the "criminals" at work. ${ }^{79}$ "“That's what free niggers come to!'" 80

The whites of the South, all the reporters agreed, were uniformly convinced that only one thing could keep the region safe and solvent - the whip, the same mechanism that had preserved slavery so long. Hardly had Carl Schurz stepped aboard the Arago leaving Washington for Hilton Head when he met a Southern planter returning with a purpose of restoring his old lands. ${ }^{81}$ Schurz asked whether he expected to make contracts with his former slaves.

This remark stirred him. He became animated .... Contracts with those niggers? It would never work. Yes, he had heard of that emancipation business. He knew that was the intention. But-and here he approached me with an air of confidentiality as if to coax my secret, true opinion out of me-now really did I think that this was a settled thing? Now, he could tell me that niggers would not work unless compelled to .... Why, was not President Johnson a Southern man, and did he not know equally well that the nigger would not work without compulsion? ${ }^{82}$

This encounter set the pattern thereafter: "[I]n at least nineteen cases of twenty," he reported to Johnson, Southerners told him flatly,

'You cannot make the negro work without physical compulsion.' I heard this hundreds of times, heard it wherever I went, heard it in nearly the same words from so many different persons, that at last I came to the conclusion that this is the prevailing sentiment among the southern people. $^{83}$

Reid found the same thing: "Nothing could overcome this rooted idea, that the negro was worthless, except under the lash," he wrote. ${ }^{84}$ Many of the "black codes" prescribed the whipping post for blacks who committed offenses that led

76. $I d$.

77. Id. at 371 .

78. TROWBRIDGE, supra note 14 , at 225.

79. Id.

80. Id.

81. CARL SChURZ, 3 REMINISCENCES OF CARL SCHURZ 159 (1908).

82. Id. at 160.

83. SCHURZ, supra note 59 , at 16 .

84. REID, supra note 11 , at 34 . 
only to fines for whites. And even some officers stationed in the South-charged with protecting the "freed" slaves - assumed that regular whipping would be part of the system, and even sometimes volunteered to administer the lash themselves on behalf of "aggrieved" whites. ${ }^{85}$

Indeed, Southern whites in 1865 and 1866 tended to agree that the whip was needed not only to make freed slaves work, but even to require them to behave in ordinary civil discourse. Whites regarded freed slaves as sullen, insolent and dangerous - often simply because the newly freed blacks resisted attempts by white to whip them. Whites tended to regard a whipping, or a beating, or even worse treatment as the prerogative of any white who was displeased by any black person, regardless of their previous relationship. Whitelaw Reid saw a Confederate veteran walk up to an armed black Union soldier: ${ }^{86}$ "Boy, le'me see your gun," the white man said casually, reaching for the soldier's weapon. ${ }^{87}$ When the black soldier refused, and raised his weapon to defend himself, the former Rebel walked away in genuine bewilderment, muttering, "How the war has demoralized the cussed brutes!" Another white told Sidney Andrews, "I would shoot one just as soon as I would a dog.",89 And, Andrews reported, he had seen a black man shot at in Columbia, South Carolina, at high noon in the doorway of a store, with no more notice taken than if the freed slave had been a domestic animal. ${ }^{90}$

Feeling this way about their former slaves, white Southerners saw no reason why "freedom" for black people should carry any additional rights, such as the right to testify in court against whites. ${ }^{91}$ Most white Southerners regularly conceded that freedom brought a right to testify-but only against another black, they thought. "I found hardly any southern man that favored admitting black testimony in cases involving whites," Schurz reported, though some would agree to consider it as a price for full restoration to the Union. ${ }^{92}$ But allowing a black witness to contradict a white person, even under oath, was unthinkable, most whites agreed. "Nothing would make me cut a nigger's throat from ear to ear so quick," a shoemaker told John Richard Dennett, "as having him set up his impudent face to tell that a thing wasn't so when I said it was so. The idea of letting one o' them be sworn to give his evidence!"'93

Not even many Northerners in 1865 favored extending the vote to blacks, either in the North or the South. Black Northerners could vote only in five states of old New England-and even there, Connecticut voters in November 1865 had roundly rejected black suffrage. ${ }^{94}$ Southerners took heart at the Connecticut vote,

85. See WILSON, supra note 69 , at 57 (stating that many enlisted men serving in the South after the war were "anti-Negro" and that one of their goals was stability and a cotton crop).

86. REID, supra note 11 , at 279.

87. See REID, supra note 11, at $410-11$ (explaining that Southern tendencies take away many civil liberties, including the ability to testify in court against white people).

88. Id.

89. ANDREWS, supra note 12 , at 100 .

90. Id.

91. REID, supra note 11 , at 410 .

92. SCHURZ, supra note 59 , at $34-35$.

93. DENNETT, supra note 7, at 75.

94. ERIC L. MCKITRICK, ANDREW JOHNSON AND RECONSTRUCTION 58-59 n.29 (1960). 
and even more comfort from a reported remark of Andrew Johnson to the governor of Missouri-"This country is for white men, and by God, as long as I am President, it shall be a country for white men." 95 After this was reported in the newspapers, one Mississippi paper adopted as its motto, "This is a white man's country-President Johnson." ${ }^{96}$

To white Southerners then, votes for the freed slaves were simply beyond imagination. "'We don't believe that because the nigger is free he ought to be saucy," one South Carolinian - a proud self-proclaimed Unionist-told Whitelaw Reid, "'and we don't mean to have any such nonsense as letting him vote. He's helpless, and ignorant, and dependent, and the old masters will still control him."'97 Riding through the sugar-plantation country of Louisiana, John Richard Dennett met a new emigrant to the south, a Massachusetts-born white who made no secret of his hatred of slavery. ${ }^{98}$ The vote, however, was something different:

[T] he men that advocated such a measure as that must be lunatics or fools .... The niggers were destitute of honesty; they didn't know the meaning of principles; they were ignorant and debased; and to put the ballot in the hands of such a set as the common plantation Negroes would be ruinous. ${ }^{99}$

Anyway, the Massachusetts man reminded Dennett, the vote was none of the Union's business. ${ }^{100}$ Since 1789 , the Constitution had allowed the states to decide who could vote and who could not. Some states allowed blacks to vote; others took the vote away from them in the early Nineteenth Century; some states, like New Jersey, had even let women vote-for a few decades after 1789, at least. ${ }^{101}$ Nothing in the Constitution gave Congress any right to meddle in the Southern states' voting practices - and the general sense was that too many white people were voting, and that blacks were out of the question. Sidney Andrews found South Carolina leaders opposed even to white voting. "It will not do to put power in the hands of the common people," they told him. Others remarked sadly, "It was a great mistake when we passed our free-suffrage law."102

The issue of black voting, however, seemed less important to Southern whites in 1865 than we might think. That is because many, if not most, whites expected the "freed slaves" to disappear, or die off, or be killed off, within a generation or two. Before the war, many anti-slavery Northerners had concluded that the only answer to the slavery question was colonization of freed slaves-either in Liberia,

95. Id. at 184 .

96. Id.

97. REID, supra note 11 , at 84.

98. DENNETT, supra note 7 , at 327.

99. Id. at 328.

100. Id.

101. See Linda K. Kerber, "Ourselves and Our Daughters Forever": Women and the Constitution, 1787-1876, in ONE WOMAN, ONE VOTE: REDISCOVERING THE WOMAN SUFFRAGE MOVEMENT 21, 27 (Marjorie Spruill Wheeler ed., 1995) (outlining a 1790 New Jersey law, repealed in 1807, explicitly referring to voters by the pronouns "he" and "she").

102. ANDREWS, supra note 12 , at 41 . 
or in Haiti, or in the American Southwest. Lincoln himself had pursued these strange-seeming colonization schemes even after issuing the Emancipation Proclamation in $1863 .{ }^{103}$ Now Southerners clutched at the idea that the federal government might simply deport the former slaves, leaving them free to cultivate their land with imported labor. Some spoke of bringing in Chinese, like those working in Western mining camps and railroads; others imagined that Europeansthen thronging the cities of the North-would flock to the South as well, to pick cotton and live in former slave cabins. But free blacks had to go. In Virginia, a Congressional candidate proclaimed that, "I shall favor and encourage the emigration and colonization of the Negro population as a measure calculated, under present circumstances, to promote the interest of both races." 104 On a train between Knoxville, Tennessee, and Atlanta, Georgia, Whitelaw Reid met a former Confederate Major, who explained "that the only effective and satisfactory policy which could be adopted was that which General Jackson had pursued towards the Indians-they must be colonized." 105

A more sinister possibility was beginning to be whispered both North and South. Black people as a race were inferior to whites. That went without saying, and was assumed by all Southerners and most of their Northern visitors. The fate of the Indians showed white Americans what happened to racial inferiors when confronted with white civilization. They simply died off; and many whites expected-eagerly or perhaps sadly, depending on their underlying feelings-that the same would happen to the freed slaves. Emancipation, this theory ran, was a poisoned chalice; without protection and supervision, the "laws of nature" doomed black Americans to extinction. "I pity the poor niggers, after what you've done for them," said one Southerner whom John Townsend Trowbridge met literally outside Andrew Johnson's office door. ${ }^{106}$ "In a little while they'll be exterminated, just like the Indians." 107 Others affected less pity for the doomed race. "I candidly confess that I look forward to the extermination of the freedmen," a Pedee River planter told John Richard Dennett. ${ }^{108}$ Among some whites, the belief sprang from the new scientific notions spread by Charles Darwin, but for most, the belief in black extinction seemed to flow out of plain wishful thinking. Trowbridge reported passengers on a Southern train who spotted through the windows a ragged camp of freemen huddled against the cold around a fire.109 "'That's freedom! That's what the Yankees have done for 'em!'" the white passengers began to cry with a grim satisfaction. "10 "They'll all be dead before spring." remarkable, he said, was that the same train was crowded with well-dressed blacks, traveling in groups to Memphis to buy Christmas presents. These passengers, who

103. See DAVID HeRBERT DONALD, LINCOLN 343-45, 430 (1995) (outlining Lincoln's various colonization ideas during the Civil War in order to deal with fugitive slaves in the North).

104. DENNETT, supra note 7 , at 76.

105. REID, supra note 11 , at 361 .

106. TROWBRIDGE, supra note 14 , at 47 .

107. Id.

108. DENNETT, supra note 7, at 191.

109. TROWBRIDGE, supra note 14, at 177.

110. Id.

111. Id. 
showed no sign of imminent demise, were in a different car, however, and the white passengers affected not to see them..$^{112}$

All in all, the prospects for the Union seemed to these Northern observers to be grim. If the South was restored on the basis Johnson proposed, the war itself might be lost even without another shot being fired. The prospect, Andrews reported, was for "a sullen and relentless antagonism to the idea of national sovereignty,-from which will breed passionate devotion to local interests, unending persecution of the freedmen, never-ceasing clamor in behalf of State rights, and continual effort to break away from the solemn obligations of the national debt." 113 Schurz warned that there was a possibility that the South would "build up another 'peculiar institution' whose spirit is in conflict with the fundamental principles of our political system." "14 Trowbridge warned that Southern leadership was determined

to govern not only their own states but to regain their forfeited leadership in the affairs of the nation; to effect the repudiation of the national debt or to get the Confederate debt and the Rebel state debts assumed by the whole country; to secure payment for their slaves, and for all injuries and losses occasioned by the war ... They consider it hard that, at the end of the bloodiest civil war that ever shook the planet, they cannot quietly slip back in their places and take up once more the scepter of political power. ${ }^{115}$

The picture of the re-emerging Slave Power was remarkably consistent among all the accounts. Of course, all were written by Northern partisans, who could be expected to sympathize with the Republican Party. But in case anyone was in doubt about the message, the Richmond Examiner ran a short report on the political situation in January 1866. No one could accuse the Examiner of Northern bias; it had been a consistent voice for secession and violence since before Sumter. Once, when Robert E. Lee suggested offering black men freedom if they would fight for the Confederacy, the Examiner had questioned the loyalty of the South's leading general. ${ }^{116}$ Now Pollard's paper announced for all to read:

Universal assent appears to be given to the proposition that if the States lately rebellious be restored to rights of representation according to the federal basis, or to the basis of numbers enlarged by the enumeration of all the blacks in the next census, the political power of the country will pass into the hands of the South, aided, as it will be, by Northern alliances. The South claims that this will be the fact, and the North does not dispute it. ${ }^{117}$

112. Id. at 177-78.

113. ANDREWS, supra note 12 , at 394.

114. SCHURZ, supra note 59 , at 46.

115. TROWBRIDGE, supra note 14 , at 316-17.

116. See James M. MCPherson, Battle Cry of Freedom: The Civil War Era 837 (C. Vann Woodward ed., 1988) (recounting Examiner's attack on Lee).

117. News from Washington, RiCHMOND EXAMINER, Jan. 9, 1866, at 1. 